Journal of Social Sciences (COES\&RJ-JSS)

ISSN (E): 2305-9249 ISSN (P): 2305-9494

Publisher: Centre of Excellence for Scientific \& Research Journalism, COES\&RJ LLC

Online Publication Date: $1^{\text {st }}$ October 2017

Online Issue: Volume 6, Number 4, October 2017

https://doi.org/10.25255/jss.2017.6.4. 827.832

\title{
Analyzing Fish Farming System in the Jordan Valley Comparative study
}

\author{
Omar M.A Adwan \\ Food Directorate \\ Jordan Food and Drug Administration (JFDA), Amman, Jordan
}

\author{
Acronyms and Abbreviation \\ FAO Food and Drug Organization \\ GDP Gross Domestic Product \\ JICA Japan International Cooperation Agency \\ MoA Ministry of Agriculture \\ JV Jordan Valley \\ NCARE National Center for Agricultural Research and Extension \\ Highlights \\ - $\quad$ Comparative study to evaluate the fish farming system in the Jordan Valley. \\ - $\quad$ Identifying the major challenges facing fish farmers in the Jordan Valley. \\ - $\quad$ Increase profitability of small scale fish farmers.
}

\begin{abstract}
:
This study aimed at analyzing fish farming system in the Jordan Valley (JV).The study examined the present position of the fish farming for small and large scale fish farmers in the JV.

Descriptive and analytical statistical methods were applied. The results showed that the major challenges and constraints faced by fish farmers were high cost of feed, weak cooperative, low price offered by traders, lack of technical knowledge and extension services, and limited access to credits.

Therefore, the study recommended strategies that can lead to an improvement in the income of farmers including strengthening the existing fish farmer's cooperative in order to organize the farmers, purchasing inputs by bulk, marketing as a group, and providing fish farmers with training in conjunction with the National Center for Agricultural Research and Extension (NCARE) specialists.
\end{abstract}

Key words:

Jordan Valley, fish farming system, irrigation ponds, NCARE.

\section{Citation:}

Adwan, Omar M.A. (2017); Analyzing Fish Farming System in the Jordan Valley Comparative study; Journal of Social Sciences (COES\&RJ-JSS), Vol.6,No.4,pp:827-832; https://doi.org/10.25255/jss.2017.6.4.827.832. 


\section{Introduction}

In Jordan, the fisheries sector contributes with less than $0.01 \%$ of Gross Domestic Product (GDP) (MoA, 2014); its contribution could be increased with more efforts to overcome the present challenges. Increasing the awareness of the nutritional value of fish and the population growth has pushed for increasing demand for fish, which is difficult to be cover by captured fish. Therefore, it is necessary to expand fish farming to meet consumer demand. The interest in this sector increased after distributing and providing valuable information on the high economic value of fish farming in artificial ponds.

Aquaculture is important as an alternative to the other types of animal protein, and it plays an important role in nutrition, food security, and livelihoods. It provides protein, essential fats, minerals and vitamins (FAO, 2016). Fish can be cultured beside agricultural projects, be as an additional source of income for farmers, and provide cash needed for other growing crops. It is possible to exploit most ponds that are used to store water and irrigate crops to raise fish and get natural fertilizer from fish waste.

In the JV, there are more than 1,000 small-scale farmers, who use their irrigation ponds for fish rearing, as most of them raise fish for home consumption and in order to clean their ponds from algae. However, few of them raise fish as additional income, since fish farming is considered to be the second source of income. Whereas, there are 21.0 commercial fish farms that raise fish for maximizing profit and consider fish farming to be their main source of income (MoA, Annual Report, 2015).

\section{Materials and methods}

\section{Description of the Study Area}

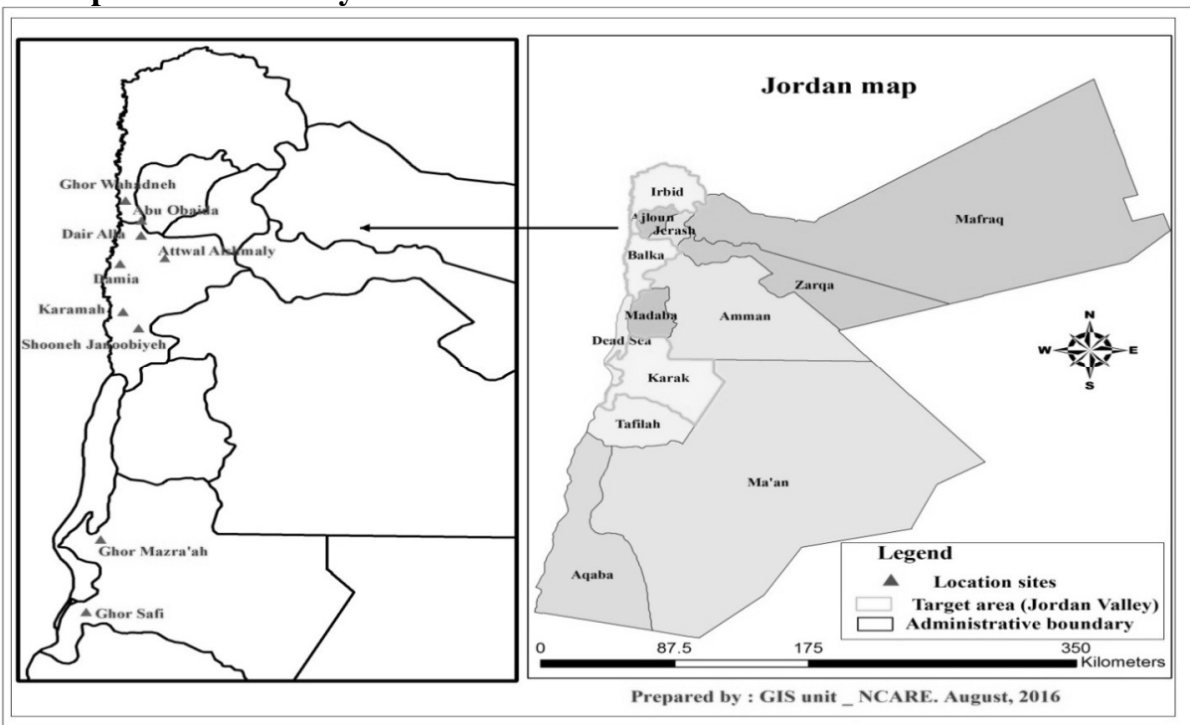

Figure 1: Map of Jordan and the study area

The JV is one of the three major areas in Jordan including the highland and the desert (Badia). It extends from the North to the South covering $350.0 \mathrm{~km}$ of fertile lands, the Dead Sea (the lowest point in the world) and the small rivers. It is situated about 200.0 to 410.0 meters below the sea level. 
Due to its warm temperature in winter, the JV is considered as a natural greenhouse and is known as the country's food basket. There are some of 0.3 million acres of the irrigated land and crops which produces various items of vegetables and fruits (DoS, 2010).

The reason behind choosing the JV to be the target area is because $75.0 \%$ of the commercial fish farms and more than 1,000 small scale farmers are located there and these fish farms produce $64.0 \%$ of the annual local fish production (MoA, 2015).

\section{Sample Selection and Composition}

Before starting the field work, a discussion was conducted with the chief of the fish Division of (NCARE) and the chief of the fish Division of Ministry of Agriculture (MoA) to select the target farmers. Thirty farmers were selected purposively in Ghor Alsafi. Those farmers who get feed and fingerlings from NCARE project for free. Also 21.0 large scale farmers were selected and they were considered to be the whole commercial farmers in the JV.

\section{Data Collection Method}

The research approach and the data collection method were discussed at the NCARE, more precisely with its Scientific Committee and with selected staff members of NCARE's Socio-Economic Department.

\section{Desk study}

A desk study review was conducted for secondary data on the economics of fish farming, fish production systems, and the challenges facing fish farming.

The secondary data were derived from various sources such as books, journals, online articles, government reports, research publications, technical and working papers, scientific, and consultancy reports of relevant institutions including (NCARE, MoA, and FAO).

The work started with a desk review of recent statistics on fish farming in terms of numbers of fish farms, production and geographical distribution. The information was used to determine the number of interviews that would be carried out in the JV.

\section{Survey}

The survey had a semi- structured questionnaire as proposed questions were developed and sent to a various specialists and researchers from the (NCARE) and the University of Jordan for their critique and suggested additions. After responses were received from the specialists and researchers, their suggestions and comments were utilized in developing the final questionnaire.

The samples selected included 51.0 holders, among which are 21.0 commercial fish farm, and 30 farms practicing fish farming in the JV.

All 51 farmers were interviewed at their various farm sites, pictures were taken from the same locations, and all the necessary data was collected using the same questionnaire. 


\section{Data Analysis and Interpretation}

Descriptive analysis was used to analyze the socio-economic characteristics of fish farmers, the production systems used by farmers, the operational cost, and the selling price of fish. The collected data from the Semi-structured questionnaire were coded and entered into the Statistical Package for the Social Sciences version 23.0 (SPSS) and analyzed.

\section{Results and discussion}

Fish farming production system

The results below revealed that both small scale and large scale farmers adopted pond system. Small farmers used extensive system and use irrigation ponds in rearing fish, while the large scale farmers investing and rearing their fish in concrete ponds.

Table 1: Characteristics of fish farming production system

\begin{tabular}{|c|c|c|c|}
\hline VARIABLE & DESCRIPTION & \multicolumn{2}{|c|}{ TYPE OF FARMER } \\
\hline Characteristics & & $\begin{array}{c}\text { Large scale } \\
\text { farmers } \\
n=21\end{array}$ & $\begin{array}{c}\text { Small scale } \\
\text { farmers } \\
n=30\end{array}$ \\
\hline Production system & & $\begin{array}{c}\text { Semi -intensive } \\
\text { system }\end{array}$ & Extensive system \\
\hline Average size of farm & Dunum* & 54.0 & 38.0 \\
\hline Type of pond & Irrigation ponds (\%) & - & 100.0 \\
\hline & $\begin{array}{l}\text { Both (earthen\& } \\
\text { concrete) } \%\end{array}$ & 100.0 & - \\
\hline Pond size & $\left(\mathrm{m}^{2}\right)$ & 2775.0 & 875.0 \\
\hline Number of ponds & & 11.0 & 1.0 \\
\hline Source of fingerlings & $\begin{array}{c}\text { On farm hatchery } \\
(\%)\end{array}$ & 25.0 & - \\
\hline & Imported $(\%)$ & 75.0 & - \\
\hline & $\begin{array}{l}\text { Government } \\
\text { hatchery }(\%)\end{array}$ & - & 100.0 \\
\hline Stocking rate & fingerlings $/ \mathrm{m}^{2}$ & 5.0 & 1.0 \\
\hline Feed source & Local feed (\%) & 30.0 & 100.0 \\
\hline & Imported feed (\%) & 70 & - \\
\hline Fish output & $\mathrm{kg} /$ farm & 49666.0 & 232.0 \\
\hline Record keeping & Yes $(\%)$ & 90.0 & - \\
\hline & No $(\%)$ & 10.0 & 100.0 \\
\hline
\end{tabular}

$* 1$ hectare $=10.0$ dunums

\section{Characteristics of fish farmers}

Findings from the descriptive analysis of socio-economic characteristics of respondents in the study area are showed that the majority of small farmers $(93.0 \%)$ had experience between 1-5 years, $73.0 \%$ of them are not members of the fish farmers cooperative and their source of finance is Japan International Cooperation Agency (JICA) project, all small scale farmers were not practicing fish farming as their main business. On the other hand large scale farmers had good experience ranging between 1-17 years, and none of them belonged to the fish cooperative. Also $57.0 \%$ of them get credit from banks as a source of finance, and all of them practiced fish farming as their main source of income. 
Table 2: Characteristics of farmers

\begin{tabular}{|c|c|c|c|c|c|}
\hline VARIABLE & CATEGORY & & TYPE 0 & FARMER & \\
\hline & & $\begin{array}{l}\text { Larg } \\
(\mathrm{n}=2\end{array}$ & ale farmers & $\begin{array}{l}\text { Small scalefa } \\
(\mathrm{n}=\mathbf{3 0})\end{array}$ & ners \\
\hline & & Freq & су $\%$ & Frequency & $\%$ \\
\hline Experience & $1-5$ years & 4.0 & 19.0 & 28.0 & 93.0 \\
\hline & 6-11 years & 10.0 & 48.0 & 2.0 & 7.0 \\
\hline & $12-17$ years & 7.0 & 33.0 & 0.0 & 0.0 \\
\hline $\begin{array}{l}\text { Membership } \\
\text { of fish } \\
\text { association }\end{array}$ & Yes & 0.0 & 0.0 & 8.0 & 27.0 \\
\hline & No & 21.0 & 100.0 & 22.0 & 73.0 \\
\hline $\begin{array}{l}\text { Source of } \\
\text { finance }\end{array}$ & Bank & 12.0 & 57.0 & 0.0 & 0.0 \\
\hline & Self & 9.0 & 43.0 & 0.0 & 0.0 \\
\hline & $\mathrm{NGO}$ & 0.0 & 0.0 & 30.0 & 100.0 \\
\hline $\begin{array}{lr}\text { Fish } & \text { farming } \\
\text { as } & \text { main } \\
\text { business } & \\
\end{array}$ & Yes & 21.0 & 100.0 & 0.0 & 0.0 \\
\hline & No & 0.0 & 0.0 & 30.0 & 100.0 \\
\hline
\end{tabular}

Source: Fish farmers survey data, 2016

\section{Conclusions}

1. The fish sector in the JV comprises producers who are small scale farmers and large scale farmers. The large scale farmers use semi - intensive system for fish production with high production due to the good experience, the use of technologies, and the good management system. Small scale farmers use extensive system for fish production with low production due to the lack of experience and knowledge, lack of technologies used in production, and poor management.

2. The major challenges and constraints faced by small scale farmers were high cost of feed, weak co-operative, low price offered by traders, lack of technical knowledge and extension services, and limited access to credits. The large scale farmers' major constraints were high cost of feed, high cost of energy, competiveness of imported fish, and lack of cold storage.

3. The majority of small and large scale farmers surveyed are not members of fish cooperatives; the cooperative is very weak and has no significant role. A strong and efficient cooperative would organize aquaculture industry, buy inputs as a bulk to reduce the costs of inputs for farmers, increase their bargaining power, and avoid exploitation of traders. There should be strategies to strengthen the chain and power of smallholder producers.

\section{Recommendations}

From the results of the study, high cost of feed, low fish price offered by middleman, and weak cooperative are the most critical problems facing small fish farmers. Since feed 
constitutes $50.0 \%$ of the cost of production, profitability can be achieved by reducing this high cost significantly and selling the fish produced to high value market. Therefore, the following recommendations are made:

1. Restructuring the existing cooperative leaderships by a re-organization of the cooperative for new leadership.

2. The leaders and members should re-write regulations with clear vision and mission to guide the cooperative.

3. Training the leaders of the cooperative to improve their management skills.

4. The cooperative must collaborate with training and research institutions such as NCARE for the training of member farmers on entrepreneurship skills to enhance their business capabilities.

5. The leaders must organise regular meetings to keep members side by side with issues on the cooperative and provide them with information on market and price.

6. Link members to banks and other micro financial institutions to provide farmers with access credit with low interest to develop their enterprises and improve their economic potential.

7. The cooperative begin sourcing for feed directly from feed companies instead of through middlemen.

8. The cooperative aggregates fish produced by farmers and sell at higher price to buyers in Amman.

\section{Acknowledgements}

The authors acknowledge the technical support from the director general of JFDA Dr. Hayel Obeidat, and the director general of NCARE, Dr. Fawzi Al Sheyyab. My special thanks to my colleagues from the NCARE, Asem Abu Alloush, Dr.Ahmad Khraisat, Tayseer Aladwan, Bashar Rahahleh, Omar Abdul Hadi, and Nael Alkawaleet for the wonderful support they offered me during data collection.

\section{References}

DoS. (2010). Jordan in Figures. Retrieved from Department of Statistics. Retrieved from http://www.dos.gov.jo/sdb/dos_home/dos_home_e/main/index.html

FAO. 2016. The State of World Fisheries and Aquaculture 2016. Contributing to food security and nutrition for all. Rome. $200 \mathrm{pp}$

MoA. (2015). Annual report. Ministry of Agriculture. Jordan

MoA. (2014). Annual report. Ministry of Agriculture. Jordan 